EUROPA REGIONUM TOM XXIII ROK 2015

DOI: $10.18276 /$ er.2015.23-19

JACEK WITKOWSKI

Politechnika Lubelska

\title{
Bariery rozwoju usług ekoturystycznych w województwie lubelskim
}

\section{Wprowadzenie}

$\mathrm{C}$ oraz więcej usługodawców prowadzących swoją działalność na obszarach wiejskich jest zainteresowanych nową formą turystyki, w której kluczową rolę odgrywa obcowanie ze środowiskiem przyrodniczym połączone z pozytywnym stosunkiem do kwestii jego ochrony ${ }^{1}$. Ekoturystyka może być szansą szczególnie dla terenów cechujących się słabiej rozwiniętą infrastrukturą gdyż fakt ten może być paradoksalnie postrzegany jako zaleta przez prawdziwych miłośników przyrody. O zaspokajanie potrzeb tych ostatnich muszą jednak zadbać kwatero dawcy, kierując do nich odpowiednie produkty turystyczne. Bez odpowiedniej wiedzy, środków oraz wsparcia zadanie to mogłoby okazać się naprawdę trudne również dla tych osób, które już obecnie prowadzą działalność usługową, lecz generalnie poprzestają na oferowaniu noclegów oraz wyżywienia. Tematem artykułu są problemy, z jakimi potencjalnie mogłaby się zetknąć ta grupa, chcąc poszerzyć swoją ofertę z myślą o zagospodarowaniu rosnącego popytu ekoturystycznego. Wnioski zostały sformułowane na podstawie badania ankietowego, którym objęto grupę właścicieli certyfikowanych gospodarstw położonych w granicach województwa lubelskiego.

\footnotetext{
${ }^{1} \mathrm{Na}$ temat definicji zob. więcej m. in. w: D. Zaręba, Ekoturystyka, Wydawnictwo Naukowe PWN, Warszawa 2006, s. 48.
} 


\section{Charakterystyka wybranej literatury przedmiotu}

Temat rozwoju usług ekoturystycznych jest coraz obficiej reprezentowany w literaturze, tym bardziej, że podejmują go zarówno naukowcy, których bardziej interesuje szeroko rozumiana problematyka rozwoju obszarów wiejskich, jak i badacze, którym bliższe są koncepcje dotyczące ochrony środowiska i przyrody. Jeśli chodzi o pozycje polskojęzyczne, można już znaleźć całe monografie poświęcone ekoturystyce, ale także publikacje, których autorzy prezentują wyniki swoich badań empirycznych przeprowadzonych na określonej grupie podmiotów lub dotyczących konkretnych obszarów. Jedną z pozycji, w której zagadnienie zostało przedstawione w sposób całościowy, jest książka D. Zaręby pt. Ekoturystyka, w której Autorka przeprowadza dyskusję samego pojęcia oraz dość obszernie omawia uwarunkowania dla rozwoju tej formy wypoczynku uwzględniając także czynniki o charakterze lokalnym. Wielostronnie do problemu podchodzi się w publikacji będącej wynikiem realizacji projektu „Eko-Roztocze” sfinansowanego w latach 2009-2010 w ramach Programu Operacyjnego Kapitał Ludzki. Wachlarz tematów jest tu szeroki, począwszy od przygotowania biznesplanu, a na wspieraniu rozwoju turystyki na poziomie regionalnym kończąc ${ }^{2}$. O różnych modelach ekoturystyki na obszarach przyrodniczo cennych pisze A. Machnik. Wyróżnia wśród nich model adaptacyjny, edukacyjny, wyrafinowany oraz rodzinny. Samą ekoturystykę nazywa elitarną formą turystyki, konkludując na podstawie własnych badań przeprowadzonych w terenie, że wielu turystów nigdy nie wyjdzie poza pierwszy z wymienionych wyżej modeli, w którym osobę wypoczywającą charakteryzuje brak doświadczenia i małe wymagania ${ }^{3}$. B. Woś porusza $w$ jednym z artykułów problem współpracy właścicieli gospodarstw agroturystycznych z pracownikami parków krajobrazowych i narodowych zauważając, że może to być sposobem tworzenia ciekawego produktu ekoturystycznego, w które mogłyby być zaangażowane również pojedyncze osoby nie zajmujące się na co dzień świadczeniem usług w turystyce, lecz obdarzone konkretnymi umiejętnościami ${ }^{4}$. Wyniki badań przeprowadzonych wśród urzędników lokalnych blin 2010

${ }^{2}$ Ekoturystyka szansq rozwoju Roztocza, red. J. Parchomiuk, Wydawnictwo „Pietrzak”, Lu-

${ }^{3}$ A. Machnik, Wybrane modele ekoturystyki realizowane na obszarach przyrodniczo cennych, „Geoturystyka” 2010, nr 2 (21), s. 22-24.

${ }^{4}$ B. Woś, Ekoturystyka szansq zrównoważonego rozwoju terenów wiejskich, „Infrastruktura i Ekologia Terenów Wiejskich” 2009, nr 5, s. 22. 
odpowiedzialnych za promocję w 57 gminach województwa małopolskiego prezentują z kolei A. Kotala i A. Niedziółka, próbując w oparciu o nie scharakteryzować stan infrastruktury ekoturystycznej w tym regionie. Autorzy ci piszą między innymi, że w Małopolsce jedną z rozpowszechnionych form agroturystyki jest agroekoturystyka, gdzie żywność w gospodarstwach produkowana jest tylko metodami ekologicznymi. Podsumowując wyniki swoich badań wytykają samorządowcom małą aktywność przy pozyskiwaniu środków unijnych na poprawę infrastruktury turystycznej połączoną $\mathrm{z}$ niedocenianiem jej roli w działaniach służących turystyce, jak również wspominają o braku możliwości skutecznego wpływania na sferę turystyczną w przypadku większości gmin $^{5}$. O formach potencjalnego wsparcia rozwoju usług ekoturystycznych przez władze lokalne pisze M. Matlegiewicz, zaliczając do nich między innymi szkolenia i doradztwo, wprowadzanie do programów nauczania w szkołach problematyki z zakresu ekologii czy też promocję produktów ekologicznych ${ }^{6}$. Autorka ta akcentuje wpływ ekoturystyki na gospodarkę obszarów wiejskich, podobnie jak S. Kulczyk i W. Lewandowski, którzy w swojej pracy traktują tę odmianę turystyki jako jedną z form zrównoważonego rozwoju?

Przykładem pracy, w której omówiono możliwości realizacji idei ekoturystyki na obszarze chronionym jest publikacja M. Mazurczaka, traktująca o przedsięwzięciach podjętych w Parku Narodowym „Ujście Warty”. Mowa jest tam nie tylko o konkretnych obiektach infrastruktury, ale także podjęto wśród innych wątek zróżnicowanego poziomu dopuszczalnego zagospodarowania turystycznego oraz natężenia ruchu turystycznego w czterech strefach o różnych funkcjach ochronnych w parkach narodowych i krajobrazowych, tj. strefie ochrony ścisłej, ochrony czynnej, ochrony krajobrazowej oraz strefie tzw. otuli$n y^{8}$. Autor niniejszego tekstu także prezentował już wyniki badań, w których

${ }^{5}$ A. Kotala, A. Niedziółka, Stan i perspektywy rozwoju infrastruktury ekoturystycznej w województwie małopolskim, „Infrastruktura i Ekologia Terenów Wiejskich” 2009, nr 5, s. 32, 36.

${ }^{6}$ M. Matlegiewicz, Ekoturystyka jako przyjazna środowisku forma turystyki, Folia Pomeranae Universitatis Technologiae Stetinensis 2009, „Oeconomica” nr 275 (57), s. 64.

${ }^{7}$ S. Kulczyk, W. Lewandowski, Ekoturystyka ,zielonq ścieżkq” do Europy, w: Studia ekologiczno-krajobrazowe $w$ programowaniu rozwoju zrównoważonego. Przeglad polskich doświadczeń u progu integracji z Uniq Europejska, red. M. Kistowski, Wydawnictwo Bogucki, Gdańsk 2004, s. 115-121.

${ }^{8}$ M. Mazurczak, Realizacja zatożeń ekoturystyki na obszarze Parku Narodowego „Ujście Warty”, „Studia i Materiały Centrum Edukacji Przyrodniczo-Leśnej” 2009, z. 23, s. 208-210. 
przedmiotem zainteresowania były produkty oferowane przez gospodarstwa agroturystyczne oraz obecność w nich komponentu ekoturystycznego?

\section{Cel, metodyka badań oraz opis próby badawczej}

W dalszej części pracy zostaną omówione wyniki badania, jakie zostało przeprowadzone na grupie 26 właścicieli obiektów infrastruktury turystycznej działających w gminach województwa lubelskiego. Celem analizy było stwierdzenie, jakie bariery widzą $\mathrm{w}$ tym, aby swoją ofertę w większym niż dotychczas stopniu kierować do osób zainteresowanych ekologią i ochroną przyrodą.

W badaniu wykorzystano metodę ankietową opartą na kwestionariuszu liczącym 33 pytania o charakterze zamkniętym. Respondenci zaznaczali odpowiedzi osobiście.

Wszystkie obiekty, których dotyczyło badanie, posiadają certyfikat Polskiej Federacji Turystyki Wiejskiej „Gospodarstwa Gościnne” i są usytuowane w różnych częściach regionu, w pobliżu obszarów cennych przyrodniczo. Niektórzy z usługodawców ze względu na propozycje kierowane pod adresem osób przyjezdnych już mogliby zostać zaliczeni do grona oferentów produktów ekoturystycznych, niemniej większość z nich koncentruje się głównie na udzielaniu noclegów wraz z wyżywieniem prowadząc działalność zbliżoną do agroturystycznej. Warto nadmienić, że wszyscy właściciele to rolnicy, dla których turystyka to uboczne źródło dochodów.

\section{Krótka charakterystyka województwa lubelskiego pod kątem uwarunkowań dla rozwoju ekoturystyki}

$\mathrm{Na}$ terenie województwa lubelskiego wystepuje stosunkowo wiele atrakcji turystycznych, które mogą potencjalnie przyciagać uwagę osób chcących uprawiać ekoturystykę. Według danych GUS z 2009 roku obszary prawnie chronione zajmują ponad $22 \%$ powierzchni województwa, na co składają się w szczególności: 2 parki narodowe (Roztoczański i Poleski), 17 obszarów chronionego krajobrazu, 17 parków krajobrazowych, 87 rezerwatów przyrody, 1402 pomniki

${ }^{9}$ M.in.: J. Witkowski, Rola gospodarstw agroturystycznych $w$ rozwijaniu ekoturystyki na obszarach przyrodniczo cennych na przykładzie wybranych obiektów działajacych $w$ powiecie bialskim, w: Turystyka na obszarach przyrodniczo cennych, red. M. Jalinik, Oficyna Wydawnicza Politechniki Białostockiej, Białystok 2010. 
przyrody, 2 zespoły przyrodniczo-krajobrazowe, 164 użytki ekologiczne, 4 stanowiska dokumentacyjne oraz 122 obszary Natura 2000. Można tam spotkać wiele cennych gatunków roślin i zwierząt, z których niektóre są unikatowe w skali kraju i Europy (np. żółw błotny w Poleskim PN) ${ }^{10}$.

Audyt turystyczny przeprowadzony na zlecenie Urzędu Marszałkowskiego w 2008 roku pokazał, że w regionie zlokalizowanych było w tamtym czasie 857 obiektów noclegowych, z czego blisko połowę stanowiły gospodarstwa agroturystyczne oraz inne obiekty wiejskie (47,5\% ogólnej liczby), przy czym wyraźnie podkreślono, że liczba ta jest zdecydowanie zaniżona $\mathrm{w}$ porównaniu $\mathrm{z}$ rzeczywistą ilością (problem ewidencjonowania). Z kolei większość obiektów bazy gastronomicznej była zlokalizowana $\mathrm{w}$ większych miastach regionu. Ponadto stwierdzono obecność 78 szlaków turystycznych pieszych o łącznej długości $3185 \mathrm{~km}$ (przyrost o około 10\% zarówno ilości jak i długości w porównaniu z 2000 rokiem), jak również ponad 30 szlaków rowerowych (potrojona ilość od 2000 roku). Odnotowano przy tym dopiero pojawianie się pierwszych szlaków konnych o charakterze lokalnym oraz brak znakowanych szlaków wodnych. W konkluzjach zwrócono uwagę między innymi na to, że wykorzystanie turystyczne obszarów prawnie chronionych na Lubelszczyźnie jest ciągle dalekie od oczekiwań oraz że słabemu nasyceniu infrastrukturą turystyczną towarzyszy małe jej zróżnicowanie i nierównomierne rozmieszczenie ${ }^{11}$.

\section{Wyniki badań}

W jednym z pytań poproszono kwaterodawców o wybranie spośród wymienionych jednego czynnika, który ich zdaniem najbardziej utrudniłby rozpoczęcie działalności w sektorze usług ekoturystycznych, gdyby zdecydowaliby się na taki rodzaj działalności. Niemal połowa osób wypełniających kwestionariusz wskazała na brak środków finansowych, podczas gdy prawie co trzeci ankietowany uznał, że najistotniejszą barierą byłby w takim przypadku brak pomocy ze strony lokalnego samorządu. Tylko trzech rolników wskazało na brak wiedzy na temat prowadzenia gospodarstwa ekoturystycznego (rys. 1).

\footnotetext{
${ }^{10}$ Program Ochrony Środowiska Województwa Lubelskiego na lata 2012-2015 z perspektywa do roku 2019, Lublin 2012 (załącznik do Uchwały Nr XXIV/398/2012, Sejmik Województwa Lubelskiego, 30 lipca 2012 r.), s. 37-38.

${ }^{11}$ Audyt Turystyczny Województwa Lubelskiego, Polska Agencja Rozwoju Turystyki, Warszawa, lipiec 2008.
} 


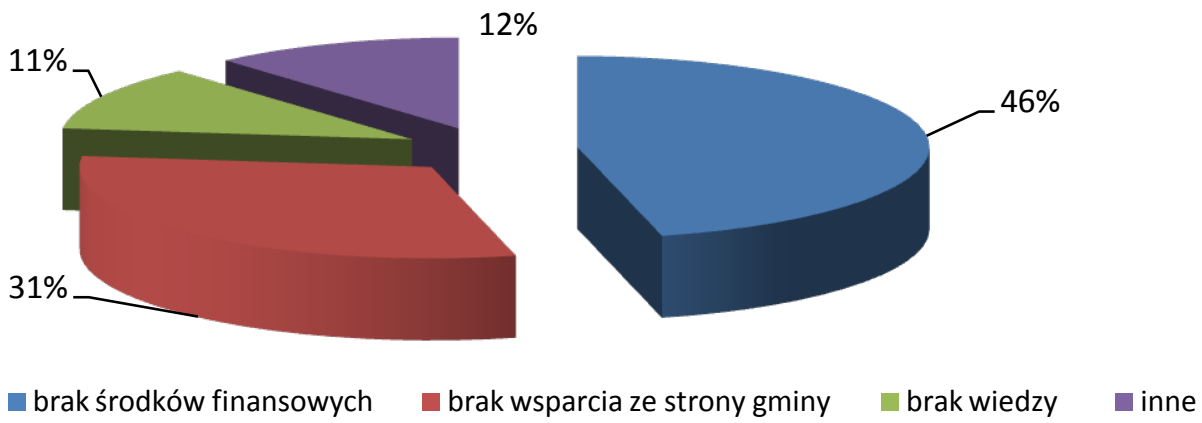

Rysunek. 1. Główny czynnik utrudniający zmianę profilu działalności usługowej w kierunku ekoturystyki

Źródło: opracowanie własne.

Prawdopodobnie duża część pytanych rolników uważa brak pieniędzy za wiodącą przeszkodę, ponieważ w ogóle negatywnie ocenia swoją sytuację materialną. Jedynie $27 \%$ respondentów ( 7 z 26) mówi o swoim położeniu ekonomicznym jako o zdecydowanie dobrym bądź raczej dobrym (rys. 2).

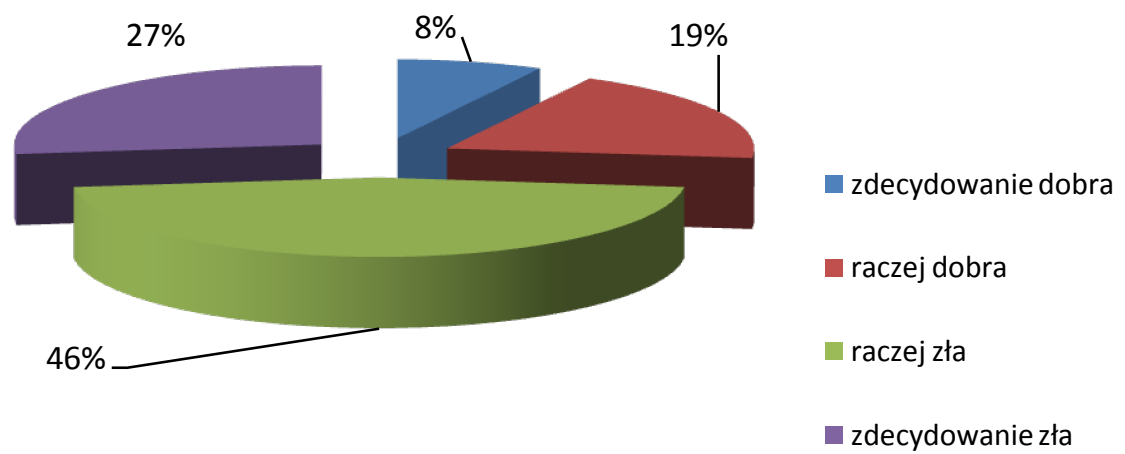

Rysunek. 2. Ocena sytuacji ekonomicznej właścicieli gospodarstw

Źródło: opracowanie własne.

Spośród pozostałych usługodawców mniej więcej co drugi stwierdza, że nie zdecydowałby się na zaangażowanie finansowe $\mathrm{w}$ nowe przedsięwzięcia. 
Z odpowiedzi udzielonych w innym miejscu wynika, że chodziłoby tu w pierwszym rzędzie o zakupy dodatkowego sprzętu oraz finansowanie własnego dokształcania (rys. 3).

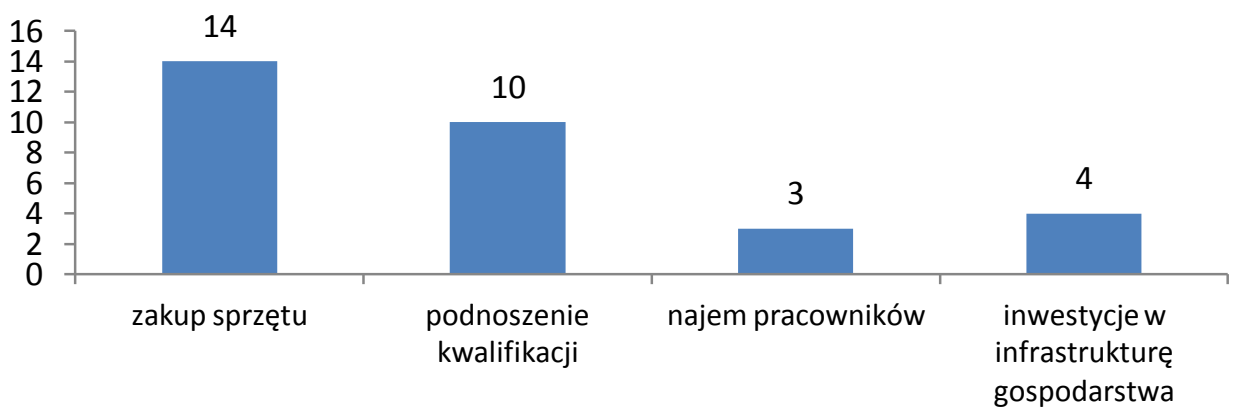

Rysunek. 3. Przeznaczenie nakładów finansowych w przypadku zmiany profilu działalności Źródło: opracowanie własne.

Dla ankietowanych poważną barierą w rozwijaniu usług ekoturystycznych jest także bierna postawa lokalnych władz, które mając do dyspozycji pewne instrumenty oddziaływania, nie wykazują dostatecznego zaangażowania we wspieranie prywatnej przedsiębiorczości w tym sektorze. Najczęściej wybieraną metodą wsparcia okazała się promocja gminy oraz terenów położonych w jej granicach (15 wskazań) (rys. 4). Wprawdzie samorządy przeważnie deklarują podejmowanie zadań związanych z marketingiem terytorialnym, co łatwo zauważyć przeglądając chociażby teksty strategii rozwoju gmin, niemniej najczęściej nie przekłada się to lub przekłada tylko w niewielkim stopniu na sferę realnych działań. Nieco mniej ważna dla respondentów jest aktywność urzędników zarówno na polu organizacji różnego rodzaju szkoleń, jak i specjalistycznego doradztwa. Zaskakuje natomiast dość małe zainteresowanie poprawą lokalnej infrastruktury ekoturystycznej, które wykazuje jedynie co piąty kwaterodawca ( 5 z 26). Trzeba przyznać, że na tym polu jest wiele do zrobienia, zwłaszcza jeśli chodzi o finansowanie przez urzędy gmin konkretnych przedsięwzięć w ramach dbania o lokalne zasoby przyrodnicze $\mathrm{i}$ ich ochronę. Jak pokazują wyniki ankiety, którą Autor przeprowadził jeszcze w 2008 roku wśród wójtów gmin lubelskich, najchętniej przeznacza się tam środki finansowe na edukację ekologiczną 
oraz sadzenie drzew i krzewów ${ }^{12}$, co z punktu widzenia osób chcących oferować produkty ekoturystyczne mogłoby okazać się niewystarczające. Tylko trzech rolników świadczących usługi turystyczne chciałoby skorzystać z ulg w podatkach i opłatach świadczonych na rzecz budżetu gminy.

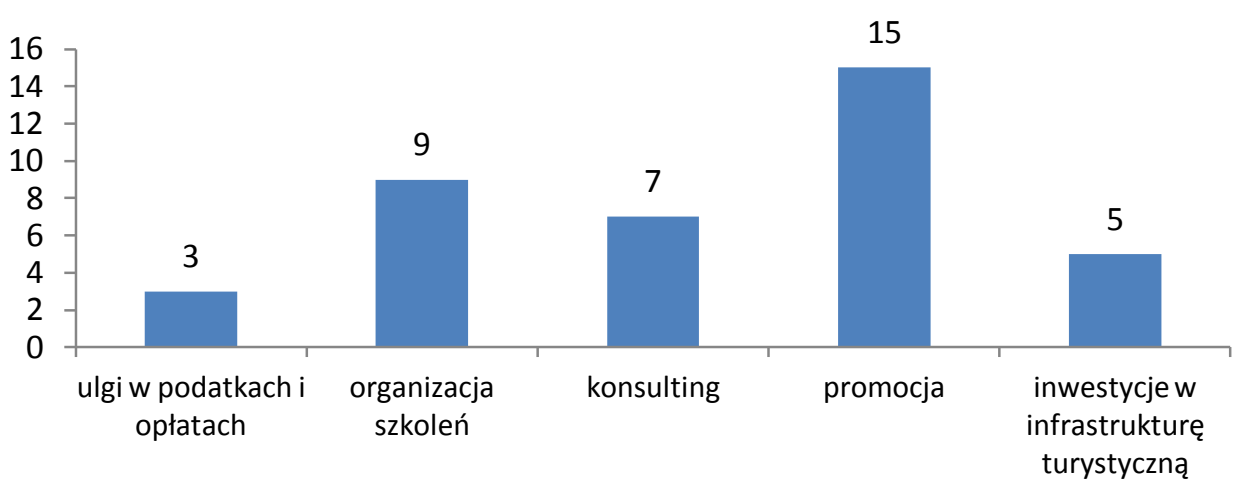

Rysunek 4. Oczekiwane formy wsparcia ze strony władz lokalnych

Źródło: opracowanie własne.

Na osobne omówienie zasługuje kwestia stosunku badanych właścicieli do posiadanej wiedzy oraz umiejętności przydatnych w nowej formie aktywności. W świetle wyników badań należy stwierdzić, że w większości uważają oni swoje kwalifikacje oraz doświadczenie już nabyte w toku dotychczasowej działalności za generalnie wystarczające dla prowadzenia działalności w ekoturystyce ( 20 z 26 respondentów), niemniej część z nich (15 właścicieli) widziałaby jednak potrzebę doskonalenia swoich umiejętności, zwłaszcza jeśli chodzi o przyjazną środowisku eksploatację zasobów przyrodniczych. Warto w tym miejscu nadmienić, że jedynie trzy osoby podały, że mają wykształcenie przyrodnicze lub mają za sobą jakieś przeszkolenie, a dwie inne zadeklarowały posiadanie uprawnień przewodnika turystycznego.

12 J. Witkowski, Zaangażowanie samorzadów gminnych $w$ działania na rzecz ochrony przyrody na przyktadzie gmin województwa lubelskiego, „Ekonomia i Środowisko” 2008, nr 1 (33), s. $123-124$. 


\section{Podsumowanie}

Rozwój ekoturystyki na danym terenie jest determinowany przez wiele czynników. Z pewnością do ważniejszych należy rozwinięta infrastruktura turystyczna, którą tworzą między innymi podmioty oferujące osobom przyjezdnym odpowiedni produkt. Na drodze kreowania tego produktu może występować wiele barier, niektóre z nich mogą wręcz uniemożliwić zaistnienie na lokalnym rynku usług ekoturystycznych.

Na podstawie wyników badań zaprezentowanych w niniejszej pracy można stwierdzić przede wszystkim występowanie problemu z potencjalnym zabezpieczeniem środków finansowych przez kwaterodawców, jak również swoiste poczucie ich osamotnienia wynikające $\mathrm{z}$ braku odpowiedniego wsparcia ze strony władz lokalnych. Od urzędników oczekiwano zwłaszcza bardziej wzmożonej akcji marketingowej oraz pomocy przy organizowaniu szkoleń i szeroko rozumianego doradztwa. Właściciele bazy noclegowej mają raczej mocne przekonanie o swojej wiedzy i umiejętnościach w kontekście prowadzenia działalności usługodawczej w ekoturystyce, choć duża ich część widziałaby jednocześnie potrzebę podnoszenia kwalifikacji. Wydaje się, że osoby te mają potencjał, który pod pewnymi warunkami mógłby zostać wykorzystany dla dobra turystyki oraz środowiska.

\section{Bibliografia}

Audyt Turystyczny Województwa Lubelskiego, Polska Agencja Rozwoju Turystyki, Warszawa, lipiec $2008 \mathrm{r}$.

Ekoturystyka szansq rozwoju Roztocza, red. J. Parchomiuk, Wydawnictwo Pietrzak, Lublin 2010.

Kotala A., Niedziółka A., Stan i perspektywy rozwoju infrastruktury ekoturystycznej w województwie malopolskim, „Infrastruktura i Ekologia Terenów Wiejskich” 2009 , nr 5.

Kulczyk S., Lewandowski W., Ekoturystyka ,zielona ścieżka” do Europy, w: Studia ekologiczno-krajobrazowe w programowaniu rozwoju zrównoważonego. Przeglad polskich doświadczeń u progu integracji z Unia Europejska, red. M. Kistowski, Wydawnictwo Bogucki, Gdańsk 2004, s. 115-121.

Machnik A., Wybrane modele ekoturystyki realizowane na obszarach przyrodniczo cennych, „Geoturystyka” 2010, nr 2 (21).

Matlegiewicz M., Ekoturystyka jako przyjazna środowisku forma turystyki, Folia Pomeranae Universitatis Technologiae Stetinensis 2009, „Oeconomica” nr 275 (57), s. $59-66$. 
Mazurczak M., Realizacja założeń ekoturystyki na obszarze Parku Narodowego „Ujście Warty”, „Studia i Materiały Centrum Edukacji Przyrodniczo-Leśnej” 2009, z. 23.

Program Ochrony Środowiska Województwa Lubelskiego na lata 2012-2015 z perspektywq do roku 2019, Lublin 2012 (załącznik do Uchwały Nr XXIV/398/2012, Sejmik Województwa Lubelskiego, 30 lipca 2012 r.).

Witkowski J., Rola gospodarstw agroturystycznych w rozwijaniu ekoturystyki na obszarach przyrodniczo cennych na przykładzie wybranych obiektów działajacych w powiecie bialskim, w: Turystyka na obszarach przyrodniczo cennych, red. M. Jalinik, Oficyna Wydawnicza Politechniki Białostockiej, Białystok 2010.

Witkowski J., Zaangażowanie samorzq̨ów gminnych $w$ dziatania na rzecz ochrony przyrody na przykładzie gmin województwa lubelskiego, „Ekonomia i Środowisko” 2008, nr 1 (33).

Woś B., Ekoturystyka szansq zrównoważonego rozwoju terenów wiejskich, „Infrastruktura i Ekologia Terenów Wiejskich" 2009, nr 5.

Zaręba D., Ekoturystyka, Wydawnictwo Naukowe PWN, Warszawa 2006.

\section{Barriers to the development of ecotourism services in Lublin province}

\section{Summary}

The theme of the article is the issue of the development of entrepreneurship in rural areas in a relatively new type of tourism, which is an ecotourism. In the initial section the most important factors for its development were briefly discuissed. In the empirical part the results of the survey were presented, which was conducted among farmers pursuing their activities in the Lublin province. The main objective of the research was to determine what obstacles the owners see in this to be able to a greater extent than previously guided their products also to those who appreciate the ecological ways of spending free time. Among the issues that were raised in the questions are: assistance from the municipal offices, expertise and economic situation. Respondents major constraint in the development of their activities see in their own difficult financial position and then point to the lack of specific top-down support. At the same time the owners of farms attach less weight to classical economic instruments, such as reductions in local taxes and fees.

Translated by: Jacek Witkowski 